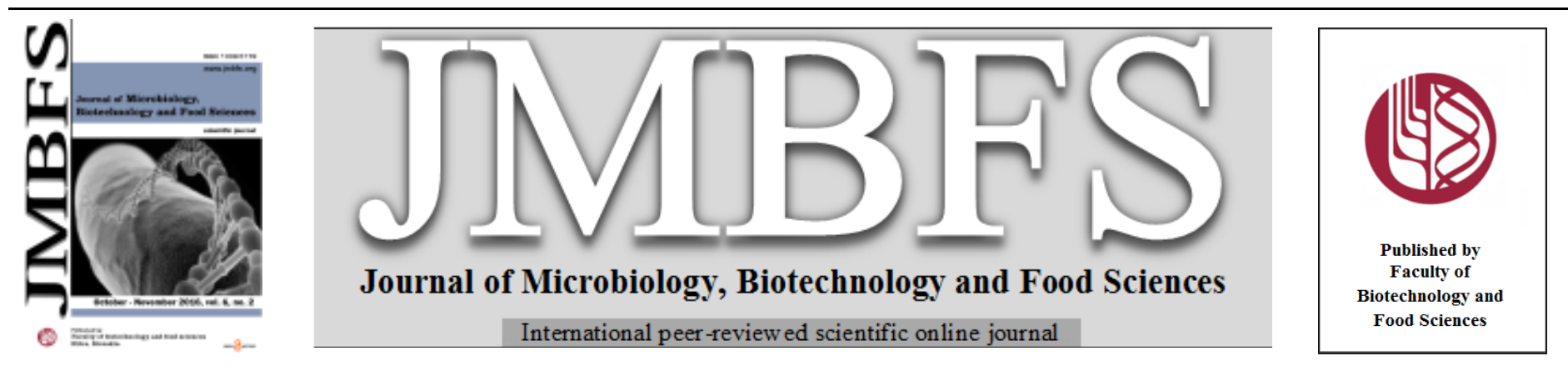

\title{
CHEMICAL AND NUTRITIONAL PROPERTIES OF SOME COMMERCIAL AVAILABLE CORN AND WHEAT PRODUCTS
}

\author{
Muhammad Usman Khan ${ }^{1}$, Majid Majeed ${ }^{2}$, Muhammad Tayyab ${ }^{3}$, Mohammad Ali Shariati ${ }^{4}$, Shilan Rashidzadeh ${ }^{5}$ \\ Address(es): \\ ${ }^{1}$ Department of Energy Systems Engineering, University of Agriculture Faisalabad,38000,Faisalabd,Pakistan,+92312667362. \\ ${ }^{2}$ National institute of Food Science and Technology, University of Agriculture, Faisalabad,38000,Faisalabd,Pakistan,+92312667362. \\ ${ }^{3}$ Punjab Bio Energy Institute,University of Agriculture Faisalabad, Faisalabad,38000,Faisalabd,Pakistan,+92312667362. \\ ${ }^{4}$ Research Department, LLC «Science \& Education», Russia and Researcher All Russian Research Institute of Phytopathology, Moscow Region, Russia. \\ ${ }^{5}$ Department of Food Science and Technology, Gorgan Payamenoor Univeristy, Gorgan, Iran.
}

*Corresponding author: engineer_usman_Khan@yahoo.com

doi: 10.15414/jmbfs.2016.6.2.863-866

\section{ARTICLE INFO}

Received 23. 6. 2016

Revised 17. 8. 2016

Accepted 15. 9. 2016

Published 3. 10. 2016

Regular article

open $\partial_{\text {Access }}$

\begin{abstract}
Commercial corn and wheat products were obtained and investigated for, proximate composition, mineral composition and tocopherol content. Proximate composition shows moisture content in the range of $28.75-2.75 \%$, ash $(2.70-0.32 \%)$, fats $(21.52-0.75 \%)$, protein $(11.540 .940 \%)$, crude fiber $(4.06-0.250 \%)$ and carbohydrates $(85.80-55.96 \%)$. The data indicate that Commercial corn and wheat products vary greatly in term of protein, fats and crude fiber. White flour and whole wheat flour were determined to contain high protein content (>10\% protein) while oil popped popcorn and biscuit contain high fats content of $>20 \%$. In minerals the level of iron is 9.56 $51.21 \mathrm{mg} / \mathrm{kg}$, Ca $(50-560 \mathrm{mg} / \mathrm{kg}), \mathrm{Zn}(1.90-32.40 \mathrm{mg} / \mathrm{kg}), \mathrm{K}(820-2946)$ and $\mathrm{Mg}(310-1512 \mathrm{mg} / \mathrm{kg})$. Tocopherol analysis was also done by the HPLC and found that Alpha tocopherol showed higher concentration than gamma and sigma tocopherol. In tocopherols level of alpha tocopherol is $0.3385-7.135 \mathrm{mg} / 100 \mathrm{~g}$, Gamma tocopherol (0.000212-9.665 mg/100g)Sigmmatocopherol (0.00212-1.685 mg/100g).
\end{abstract}

Keywords: Proximate composition, minerals, tocopherol, maize, wheat

\section{INTRODUCTION}

Cereals are mostly grasses cultivated for their edible grains. These are grown at larger areas in Pakistan and cereal give more energy than any other type of crop worldwide. They are also a rich source of carbohydrate, protein, vitamins, fiber and minerals. In some developing countries, wheat or corn constitutes entire diet of poor people. In developed countries, cereal consumption is both more moderate but consumption is still substantial. In Pakistan wheat, maize and rice are grown at larger areas and these are the major energy source in the whole world than any other cereal crop. In developing countries wheat, rice and maize are the major constitutes of the entire diet of poor people. In Pakistan wheat (TriticumaestivumL.) is main food crop and used as staple food in country. In agricultural policies wheat it occupies a central position. In agriculture wheat contributes 12.5 percent to the value added and $2.9 \%$ contribute to GDP. Its annual production was about 18.47 million tons and it is cultivated on an area of 8 million hectares in 2007-2008. At village stage, the storage space contains mud containers, metal containers, concrete rooms, jute hand bags and wood made bins. Open storage by putting bagged grain on plinth is also practiced by the whole sellers and for the protection it is covered with tarpaulin. Post-harvest losses are quite substantial because of poor drying and storage facilities (Baloch and Irshad, 1986).

In Pakistan, maize is the third most important cereal crop after wheat and rice and is used as a staple food for humans, as feed for livestock and as raw material for industry. During 2006, it was planted on 1030 thousand hectares in Pakistan, with total production of 3560 thousand tons and having an average yield of 3.458 tons ha-1 (Khan et al., 2009). Maize accounts for $4.8 \%$ of the total cropped area and $3.5 \%$ of the value of agricultural output of Pakistan. It is planted on an estimated area of 0.9 million hectare with an annual production of 1.3 million tones. The bulk $(97 \%)$ of the total production come from two major provinces (NWFP and Punjab), NWFP, accounting for $57 \%$ of the total area and $68 \%$ of total production (PARC, 2007).

World collections of maize comprise about 12,000 accessions that are represented in 256 races, of which about 30 are in the process of extermination. Genetic erosion and habitat destruction by modern agriculture has increased the importance of germplasm characterization of plant materials (Carvalho et al., 2004). Maize and wheat are a multipurpose crop, providing food and fuel for human beings, feed for animals, poultry and livestock. Its grains have great nutritional value and are used as raw material for manufacturing many industrial products (Afzal et $\boldsymbol{a l . , 2 0 0 9 )}$. Its grains are important for the production of oil, starch and glucose (Niaz and Dawar, 2009). Moreover, food composition data is important in nutritional planning and provides data for epidemiological studies (Ali et al., 2008). However, there is limited information about the nutritional composition of the different commercial corn and wheat products which are manufactured in Pakistan. The present study aims to investigate, proximate composition, mineral and tocophero composition of the different commercial corn and wheat products which are manufactured in Punjab province of Pakistan.

\section{MATERIALS AND METHODS}

\section{Moisture content}

The moisture content in the fortified whole wheat flour samples was determined in an air forced draft oven (Memmert) by following the method described in AACC [2000].

\section{Ash content}

Each flour sample was tested for ash content using muffle furnace (NEY M-525) by following the procedure outlined in AACC [2000].

\section{Fat content}

The crude fat content in whole wheat flour samples was estimated using petroleum ether as a solvent in Soxhlet apparatus (Sox. Tec System H T- 2, 1045) according to the procedure given in AACC [2000].

\section{Protein content}

The nitrogen content in flour samples was determined by Kjeldahl's method as described in AACC [2000]. The nitrogen percentage was determined as:

$$
\text { Nitrogen } \%=\frac{\text { Vol. of } 0.1 \mathrm{~N} \mathrm{H} 2 \mathrm{SO} 4 \text { used } \times 0.0014 \times 250}{\text { Weight of sample }(\mathrm{g}) \times \text { Vol. of diluted sample used }} \times 100
$$


The protein percentage was calculated by multiplying $\%$ nitrogen with a factor 5.7

\section{Crude fiber}

The crude fiber of corn products were determined as mentioned in AACC Method No. 32-10. Moisture free and fat free sample was used for this study.

\section{Nitrogen Free Extract (NFE)}

Nitrogen free extract was calculated by subtracting the percentages of moisture, protein, fat, fiber and ash from 100 as follows:

$\mathrm{NFE}=100-($ moisture $\%+$ crude protein $\%+$ crude fat $\%+$ crude fiber $\%+$ ash $\%)$

\section{Mineral composition:}

Mineral content was determined by inductively coupled plasma-optical emission spectrometry (ICP-OES) (Zand et al., 2011).

\section{Sample digestion}

Each sample was mixed and homogenized using a domestic blender and three independent replicates of $0.5 \mathrm{~g}$ were weighed prior to adding $10 \mathrm{~mL}$ of concentrated $\mathrm{H}_{2} \mathrm{SO}_{4}$ (overnight) then added $1 \mathrm{~mL} \mathrm{H}_{2} \mathrm{O}_{2}$ and digest it on the hot plate at $150{ }^{\circ} \mathrm{C}$ until white fumes comes out and transparent solution will obtained. Remove the solution and cool it. Then diluted upto $50 \mathrm{~mL}$ vol. flask and filtered the solution with the help of whatman No.1 filter paper.

\section{Analysis by Inductivity Coupled Plasma-Optical Emission Spectrometer (ICP-OES)}

$9 \mathrm{~mL}$ digested samples were quantitatively analyzed using an Inductivity Coupled Plasma-Optical Emission Spectrometer. Working solution of certain concentration are run to see the performance and linearity behavior of instrument. We calculate the concentration by using formulae:

Conc. in sample $=$ Conc. $\times$ Dilution Factor $/$ Weight of sample

\section{Tocopherol analysis}

\section{Materials}

For the analysis, oil was extracted from commercial corn and wheat products Standard of alpha-tocopherolwas purchased from Aldrich (Steinheim, Germany), Sigmma and Gamma tocopherols were from Sigma (St. Louis, USA). All solvents were of HPLC grade.

\section{Sample Preparation}

The sample preparation and analysis of Tocopherol in corn and wheat products were performed as described in method (Swiglo and Sikorska, 2004). Sample of corn and wheat products were weighed $(0.0400$ to $0.1200 \mathrm{~g})$ and dissolved in $1 \mathrm{~mL}$ of 2-propanol. The selection of 2-Propanol was chosen because it allows solubility of oils and it is miscible with all solvents used in chromatography. Thus, no additional sample treatment is necessary. Vortexed-mixed samples were directly injected onto HPLC column. Stock and working solutions of tocopherols were also prepared in 2-propanol. Sample and standard solutions were prepared directly before analysis.Care was taken to exclude air and light exposure of sample and standard solutions throughout the analytical procedure.

\section{HPLC analysis of tocopherols}

All HPLC analyses of tocopherols were performed at room temperature on Shimadzu LC-10A high performance liquid chromatograph (Shimadzu, Kyoto, Japan) equipped with Discovery supelco C18 $(250 \mathrm{~mm} \times 4.6 \mathrm{~mm}, 5 \mu \mathrm{m}$, MA, USA). For determination of tocopherols in oils, a mobile phase consisting of $50 \%$ of acetonitrile (solvent A) and $50 \%$ of methanol (solvent B) was used with the flow rate $1.5 \mathrm{~mL}$ min-1. Injection volume was $20 \mu \mathrm{l}$. The eluate was detected using a fluorescence detector (RF-530) set at emission wavelength of $325 \mathrm{~nm}$ with an excitation at $295 \mathrm{~nm}$. Tocopherols were identified by comparing their retention times with those of corresponding standards and by spiking of samples with appropriate standard.

\section{RESULTS AND DISSUSIONS}

\section{Proximate compostion corn and wheat products}

The mean values for moisture content of different corn and wheat samples have been shown in the Table 1 . The moisture content of different products of wheat ranged from the $3.40-28.75 \%$. Among the products higher moisture content $(28.75 \%)$ was noted in the bread followed by the $(12.08 \%)$ in the white flour, $(11.20 \%)$ in wheat flour and $(3.40 \%)$ in the biscuit. Similar results for the moisture content in the wheat samples were obtained by (Parveen, 2007; Rehman, 2011). While the result pertaining to the moisture content of commercial corn samples have been given in Table 1. Among these samples higher moisture content was determined in corn flour $(9.50 \%)$ followed by the air popped popcorn $(9.0 \%)$, oil popped popcorn $(2.82 \%)$ and corn flakes $(2.75 \%)$. The result of this study are in close agreement with the finding of (Padovani et al. 2007; Akram et al., 2011). The ash content in the wheat samples varied from $0.32-0.90 \%$. The result showed that maximum ash content was found in the bread $(0.90 \%)$. Lowest was observed inwhite flour $(0.32 \%)$. Mean values of all samples of corn are presented in the Table 1. The highest value of ash $(2.70 \%)$ was determined in oil popped popcorn followed by the corn flakes $(1.90 \%)$, Air popped popcorn $(1.72 \%)$ and corn flour $(0.40 \%)$. The crude fat content in the wheat samples varied from $1.32-21.52 \%$. Among the samples higher fat content $(21.52 \%)$ was noted in the biscuit followed by the $(6.09 \%)$ bread, $(1.67 \%)$ in wheat flour and $(1.32 \%)$ in the white flour. Among corn samples higher crude fat content was determined in oil popped popcorn (26\%) followed by the air popped popcorn $(3.9 \%)$, corn flour $(1.06 \%)$ and corn flakes $(0.75 \%)$. Highest amount of crude fat is determined in the oil popped popcorn because these popcorn are fried in the oil. . The crude fiber content in the wheat products varied from 0.25 $1.14 \%$. The result showed that maximum crude fiber content was found in the wheat flour $(1.14 \%)$. Lowest was observed in biscuit $(0.25 \%)$. Crude fiber content for the different corn products were significantly different from each other The highest value of crude fiber $(4.06 \%)$ was determined in the air popped popcorn followed by the oil popped popcorn $(3.40 \%)$, corn flakes. $(3.00 \%)$ and corn flour $(2.30 \%)$. The crude protein content in the wheat samples varied from $7.75-11.54 \%$. Among the products higher protein content $(11.54 \%)$ was noted in the white flour followed by the $(10.71 \%)$ wheat flour, $(9.21 \%)$ in biscuitsand $(7.75 \%)$ in bread. Among corn products higher crude protein content was determined in oil popped popcorn $(8.74 \%)$ followed by the air popped popcorn $(8.67 \%)$, corn flakes $(6.26 \%)$ and corn flour $(0.940 \%)$. The mean values for NFE content of different wheat products have been shown in the Table 1 The NFE content in the wheat samples varied from 55.96-74.54\%. The minimum mean value of NFE was found in bread $(55.96 \%)$ followed by the biscuit $(65.02 \%)$, white flour $(74.20 \%)$ and wheat flour $(74.54 \%)$.

\section{Mineral composition}

Iron content for the different wheat products which include $\mathrm{T}_{1}, \mathrm{~T}_{2}, \mathrm{~T}_{3}$, and $\mathrm{T}_{4}$ was ranged from 9.59 to $51.21 \mathrm{mg} / \mathrm{kg}$. The highest value of iron $(51.21 \mathrm{mg} / \mathrm{kg})$ was determined in the $\mathrm{T}_{1}$ followed by the $\mathrm{T}_{3}(36.42 \mathrm{mg} / \mathrm{kg}), \mathrm{T}_{4}(28.75 \mathrm{mg} / \mathrm{kg})$ and $\mathrm{T}_{2}$ $(9.59 \mathrm{mg} / \mathrm{kg})$. The results were comparable with the finding of Padovaniet al (2007). They compared proximate, mineral and vitamin composition of common foods. Kadamet al. (2012) also found the similar results. They determined the iron content in whole wheat flour. Three elements group after milling showed major decrease in the concentration, i.e., $\mathrm{Fe}, \mathrm{Mg}$ and $\mathrm{Zn}$. Aleurone layer particularly abundant with these metals. Iron content was determined in the different corn samples which include $S_{1}, S_{2}, S_{3}$ and $S_{4}$. The highest value of iron $(41.06 \mathrm{mg} / \mathrm{kg})$ was determined in $S_{2}$ followed by the $S_{3}(27.90 \mathrm{mg} / \mathrm{kg}), S_{4}(26.70$ $\mathrm{mg} / \mathrm{kg})$ and $S_{1}(11.1 \mathrm{mg} / \mathrm{kg})$. Calcium content for the different wheat samples was ranged from 38.49 to $355.20 \mathrm{mg} / \mathrm{kg}$. The highest value of calcium $(355.2$ $\mathrm{mg} / \mathrm{kg}$ ) was determined in $\mathrm{T}_{1}$ followed $\mathrm{T}_{4}(230 \mathrm{mg} / \mathrm{kg}), \mathrm{T}_{2}(180.50 \mathrm{mg} / \mathrm{kg}), \mathrm{T}_{3}$ $(38.49 \mathrm{mg} / \mathrm{kg})$. Calcium content for the different corn products were ranged from 50 to $560 \mathrm{mg} / \mathrm{kg}$. The highest value of calcium $(560 \mathrm{mg} / \mathrm{kg})$ was determined in $\mathrm{S}_{2}$ followed by $\mathrm{S}_{3}(100.21 \mathrm{mg} / \mathrm{kg}), \mathrm{S}_{4}(98 \mathrm{mg} / \mathrm{kg})$ and $\mathrm{S}_{1}(50 \mathrm{mg} / \mathrm{kg})$. Zinc content for the different wheat samples was ranged from 7.89 to $26.35 \mathrm{mg} / \mathrm{kg}$. The highest value of calcium $(26.35 \mathrm{mg} / \mathrm{kg})$ was determined in $\mathrm{T}_{3}$ followed by $\mathrm{T}_{1}(17.32$ $\mathrm{mg} / \mathrm{kg}), \mathrm{T}_{2}(8.40 \mathrm{mg} / \mathrm{kg}), \mathrm{T}_{4}(7.89 \mathrm{mg} / \mathrm{kg})$. Zinc content for the different corn samples were ranged from 1.90 to $32.40 \mathrm{mg} / \mathrm{kg}$. The highest value of calcium $(32.40 \mathrm{mg} / \mathrm{kg})$ was determined in $\mathrm{S}_{4}$ followed by $\mathrm{S}_{3}(25.40 \mathrm{mg} / \mathrm{kg}), \mathrm{S}_{1}(7.22$ $\mathrm{mg} / \mathrm{kg})$ and $\mathrm{S}_{2}(1.90 \mathrm{mg} / \mathrm{kg})$. Potassium content for the different wheat samples was ranged from 990 to $2468 \mathrm{mg} / \mathrm{kg}$. The highest value of potassium (2468 $\mathrm{mg} / \mathrm{kg})$ was determined in $\mathrm{T}_{4}$ followed by $\mathrm{T}_{1}(1810.6 \mathrm{mg} / \mathrm{kg}), \mathrm{T}_{2}(1511 \mathrm{mg} / \mathrm{kg})$ and $\mathrm{T}_{3}(990 \mathrm{mg} / \mathrm{kg})$. Potassium content for the different corn samples which include $S_{1}, S_{2}, S_{3}$ and $S_{4}$. The highest value of potassium $(2946 \mathrm{mg} / \mathrm{kg})$ was determined in $S_{4}$ followed by $S_{3}(2210 \mathrm{mg} / \mathrm{kg}), S_{1}(1620.5 \mathrm{mg} / \mathrm{kg})$ and $S_{2}(820$ $\mathrm{mg} / \mathrm{kg}$ ). Magnesium content for the different wheat products was ranged from $106.5-1512 \mathrm{mg} / \mathrm{kg}$. The highest value of Magnesium $(1512 \mathrm{mg} / \mathrm{kg})$ was determined in $\mathrm{T}_{3}$ followed by $\mathrm{T}_{1}(943.80 \mathrm{mg} / \mathrm{kg}), \mathrm{T}_{2}(310 \mathrm{mg} / \mathrm{kg})$, and $\mathrm{T}_{4}(106.4$ $\mathrm{mg} / \mathrm{kg}$ ). Kadam et al., 2012). Magnesium content for the different corn samples which include $S_{1}, S_{2}, S_{3}$ and $S_{4}$. Range of magnesium content was from 79 to $1310 \mathrm{mg} / \mathrm{kg}$. The highest value of Magnesium $(1310 \mathrm{mg} / \mathrm{kg})$ was determined in $\mathrm{S}_{4}$ followed by $\mathrm{S}_{3}(1060 \mathrm{mg} / \mathrm{kg}), \mathrm{S}_{2}(505 \mathrm{mg} / \mathrm{kg})$ and $\mathrm{S}_{1}(400 \mathrm{mg} / \mathrm{kg})$.

\section{Tocopherol analysis}

Comparison of mean of wheat samples which include $T_{1}, T_{2}, T_{3}$ and $T_{4}$ showed that higher amount of Alpha-tocopherol exists in $\mathrm{T}_{4}(7.135 \mathrm{mg} / 100 \mathrm{~g})$ followed by 
$\mathrm{T}_{1}(4.21 \mathrm{mg} / 100 \mathrm{~g}), \mathrm{T}_{2}(3.67 \mathrm{mg} / 100 \mathrm{~g})$ and $\mathrm{T}_{3}(1.52 \mathrm{mg} / 100 \mathrm{~g})$ as shown in the Table 4.30. The finding of present study are in line with the finding of (Piironen et al., 1986). Even if cereal tocols vary in dependence on genotype and location. They reported that the richest source is wheat germ. The germ contains lipids, vitamins, and minerals. The lipids mostly consist of linolenic acid $(2.3 \mathrm{Wt}$. \%), linoleic (55 Wt. \%) and oleic (1 8 Wt. \%) (Kulp and Ponte, 2000).Tocopherol is the major fat soluble vitamin which is present in the germ. Corn products which include $S_{1}, S_{2}, S_{3}$ and $S_{4}$. Among these samples Alpha-tocopherol content was ranged from 0.3385 to $5.885 \mathrm{mg} / 100 \mathrm{~g}$. The highest value of alpha-tocopherol $(5.885 \mathrm{mg} / 100 \mathrm{~g})$ was determined $\mathrm{S}_{3}$ followed by $\mathrm{S}_{2}(3.59 \mathrm{mg} / 100 \mathrm{~g}), \mathrm{S}_{4}(1.70$ $\mathrm{mg} / 100 \mathrm{~g})$ and $\mathrm{S}_{1}(0.3385 \mathrm{mg} / 100 \mathrm{~g})$. Gamma-tocopherol content for the differen wheat products was ranged from 0.0002 to $2.81 \mathrm{mg} / 100 \mathrm{~g}$. The highest value of Gamma-tocopherol $(2.62 \mathrm{mg} / 100 \mathrm{~g})$ was determined in $\mathrm{T}_{3}$ followed by $\mathrm{T}_{4}(1.197$ $\mathrm{mg} / 100 \mathrm{~g}), \mathrm{T}_{2}(0.430 \mathrm{mg} / 100 \mathrm{~g})$ and $\mathrm{T}_{1}(0.000212 \mathrm{mg} / 100 \mathrm{~g})$. The analysis of varience of gamma- tocopherol content in different samples of wheat are shown in the Table 4.33. Our results are also in good agreement with the finding of (Piironen et al., 1986). Even if cereal tocols vary in dependence on genotype and location. They determined the tocopherol and tocotrienols in cereals from Finland. Our results are also supported by Panfiliet al. (2003). Nielsen and Hansen (2008) reported that gamma tocopherol is in traces in wheat flour. Corn samples which include $S_{1}, S_{2}, S_{3}$ and $S_{4}$. Among these samples Gammatocopherol content was ranged from 10.33 to $0.565 \mathrm{mg} / 100 \mathrm{~g}$. The highest value of Gamma-tocopherol $(9.665 \mathrm{mg} / 100 \mathrm{~g})$ was determined in $\mathrm{S}_{4}$ followed by $\mathrm{S}_{2}$ $(8.255 \mathrm{mg} / 100 \mathrm{~g}), \mathrm{S}_{3}(2.77 \mathrm{mg} / 100 \mathrm{~g})$ and $\mathrm{S}_{1}(0.5285 \mathrm{mg} / 100 \mathrm{~g})$. Swiglo and Sikorska (2004) also found the similar results. They determined that Gammatocopherol in corn oil is more than the alpha and sigma tocopherol. Akram (2011) determined the tocopherol contents of commercially available corn products. Our result are in line with the finding of Akram (2011). Piironenet al. (1986) determined the tocopherol and tocotrienols in cereals from Finland. Our results are also in good agreement with the finding of Piironen et al. (1986). Comparison of mean of wheat samples which include $T_{1}, T_{2}, T_{3}$ and $T_{4}$ showed that higher amount of Sigma-tocopherol exists in $\mathrm{T}_{4}(0.6455 \mathrm{mg} / 100 \mathrm{~g})$ followed by $\mathrm{T}_{3}(0.3965 \mathrm{mg} / 100 \mathrm{~g}), \mathrm{T}_{2}(0.0888 \mathrm{mg} / 100 \mathrm{~g})$ and $\mathrm{T}_{1}(0.00194 \mathrm{mg} / 100 \mathrm{~g})$. Our results are also in good agreement with the finding of (Piironen et al., 1986). They determined the sigma tocopherol from different cereal products which are in close agreement with our finding. Nielsen and Hansen (2008) reported that gamma tocopherol is in traces in wheat flour. Our results are aslo supported by Panfili et al. (2003). Sigma-tocopherol content for the different corn samples was ranged from $0.0144-1.685 \mathrm{mg} / 100 \mathrm{~g}$. The highest value of sigma-tocophero $(1.685 \mathrm{mg} / 100 \mathrm{~g})$ was determined in $\mathrm{S}_{4}$ followed by $\mathrm{S}_{2}(1.225 \mathrm{mg} / 100 \mathrm{~g}), \mathrm{S}_{3}$ $(0.3135 \mathrm{mg} / 100 \mathrm{~g})$ and $\mathrm{S}_{1}(0.0144 \mathrm{mg} / 100 \mathrm{~g})$. Our results are also in good agreement with the finding of (Piironen et al., 1986). They determined the tocopherol and tocotrienols in cereals from Finland. Our results are also comparable with finding of Akram (2011). They determined the nutritive quality and aflatoxins contents of commercially available corn products.

Table 1 Proximate composition of commercial corn and wheat products

\begin{tabular}{lcccccc}
\hline Treatment & Moisture & Ash & Fat & Fiber & Protein & NFE \\
\hline Wheat flour & $11.20^{\mathrm{b}}$ & $0.74^{\mathrm{ab}}$ & $1.67^{\mathrm{c}}$ & $1.14^{\mathrm{a}}$ & $10.71^{\mathrm{b}}$ & $74.54^{\mathrm{a}}$ \\
White flour & $12.08^{\mathrm{b}}$ & $0.32^{\mathrm{c}}$ & $1.32^{\mathrm{c}}$ & $0.46^{\mathrm{b}}$ & $11.54^{\mathrm{a}}$ & $74.20^{\mathrm{a}}$ \\
Bread & $28.75^{\mathrm{a}}$ & $0.90^{\mathrm{a}}$ & $6.09^{\mathrm{b}}$ & $0.55^{\mathrm{b}}$ & $7.75^{\mathrm{d}}$ & $55.96^{\mathrm{c}}$ \\
Biscuits & $3.40^{\mathrm{c}}$ & $0.60^{\mathrm{b}}$ & $21.52^{\mathrm{a}}$ & $0.250^{\mathrm{a}}$ & $9.21^{\mathrm{c}}$ & $65.02^{\mathrm{b}}$ \\
Corn flour & $9.50^{\mathrm{a}}$ & $0.40^{\mathrm{c}}$ & $1.06^{\mathrm{c}}$ & $2.30^{\mathrm{d}}$ & $0.940^{\mathrm{c}}$ & $85.80^{\mathrm{a}}$ \\
Corn flakes & $2.75^{\mathrm{c}}$ & $1.90^{\mathrm{b}}$ & $0.75^{\mathrm{c}}$ & $3.0^{\mathrm{c}}$ & $6.26^{\mathrm{b}}$ & $85.34^{\mathrm{a}}$ \\
$\begin{array}{l}\text { Oil popped } \\
\text { popcorn }\end{array}$ & $2.82^{\mathrm{c}}$ & $2.70^{\mathrm{a}}$ & $26.0^{\mathrm{a}}$ & $3.40^{\mathrm{b}}$ & $8.74^{\mathrm{a}}$ & $56.34^{\mathrm{c}}$ \\
$\begin{array}{l}\text { Air popped } \\
\text { pop corn }\end{array}$ & $9.00^{\mathrm{a}}$ & $1.72^{\mathrm{b}}$ & $3.9^{\mathrm{b}}$ & $4.06^{\mathrm{a}}$ & $8.67^{\mathrm{a}}$ & $72.64^{\mathrm{b}}$ \\
\hline
\end{tabular}

Note: Values in each row having the same letters are not significantly different $(\mathrm{p}>0.05)$ Values in each column having the superscript values are not significantly different $(\mathrm{p}>0.05)$.

Table 2 Mineral composition of commercial corn and wheat products $(\mathrm{mg} / \mathrm{kg})$

\begin{tabular}{lccccc} 
Treatment & Iron & Calcium & Zinc & Potassium & Magnesium \\
\hline Wheat flour & $51.21^{\mathrm{a}}$ & $355.20^{\mathrm{a}}$ & $17.32^{\mathrm{b}}$ & $1810.6^{\mathrm{b}}$ & $943.80^{\mathrm{b}}$ \\
White flour & $9.56^{\mathrm{d}}$ & $180.50^{\mathrm{c}}$ & $8.40^{\mathrm{c}}$ & $1511^{\mathrm{c}}$ & $310^{\mathrm{c}}$ \\
Bread & $36.42^{\mathrm{b}}$ & $38.49^{\mathrm{d}}$ & $26.35^{\mathrm{a}}$ & $990^{\mathrm{d}}$ & $1512^{\mathrm{a}}$ \\
Biscuits & $28.75^{\mathrm{c}}$ & $230^{\mathrm{b}}$ & $7.89^{\mathrm{c}}$ & $2468^{\mathrm{a}}$ & $106.40^{\mathrm{d}}$ \\
Corn flour & $11.11^{\mathrm{c}}$ & $50.0^{\mathrm{b}}$ & $7.22^{\mathrm{c}}$ & $1620.5^{\mathrm{c}}$ & $400^{\mathrm{d}}$ \\
$\begin{array}{l}\text { Corn flakes } \\
\text { Oil popped }\end{array}$ & $41.06^{\mathrm{a}}$ & $560^{\mathrm{a}}$ & $1.90^{\mathrm{d}}$ & $820^{\mathrm{d}}$ & $505^{\mathrm{c}}$ \\
popcorn & $27.90^{\mathrm{b}}$ & $100.21^{\mathrm{b}}$ & $25.40^{\mathrm{b}}$ & $2210^{\mathrm{b}}$ & $1060^{\mathrm{b}}$ \\
Air popped pop & & & & & \\
corn & $26.70^{\mathrm{b}}$ & $98^{\mathrm{b}}$ & $32.40^{\mathrm{a}}$ & $2946^{\mathrm{a}}$ & $1310^{\mathrm{a}}$
\end{tabular}

Note: Values in each row having the same letters are not significantly differen $(p>0.05)$. Values in each column having the superscript values are not significantly different $(\mathrm{p}>0.05)$.
Table 3 Tocopherol composition of commercial corn and wheat products (mg/ $100 \mathrm{~g})$

\begin{tabular}{lccc}
\hline Treatment & $\begin{array}{c}\text { Alpha- } \\
\text { Tocopherol }\end{array}$ & $\begin{array}{c}\text { Gamma- } \\
\text { Tocopherol }\end{array}$ & SigmmaTocopherol \\
\hline Wheat flour & $4.21^{\mathrm{b}}$ & $0.000212^{\mathrm{d}}$ & $0.00212^{\mathrm{c}}$ \\
White flour & $3.67^{\mathrm{b}}$ & $0.430^{\mathrm{c}}$ & $0.0888^{\mathrm{c}}$ \\
Bread & $1.52^{\mathrm{c}}$ & $2.625^{\mathrm{a}}$ & $0.3965^{\mathrm{b}}$ \\
Biscuits & $7.135^{\mathrm{a}}$ & $1.197^{\mathrm{b}}$ & $0.6455^{\mathrm{a}}$ \\
Corn flour & $0.3385^{\mathrm{d}}$ & $0.5285^{\mathrm{c}}$ & $0.0144^{\mathrm{c}}$ \\
Corn flakes & $3.59^{\mathrm{b}}$ & $8.255^{\mathrm{a}}$ & $1.225^{\mathrm{b}}$ \\
Oil popped & $5.885^{\mathrm{a}}$ & $2.77^{\mathrm{b}}$ & $0.3135^{\mathrm{c}}$ \\
popcorn & & & \\
Air popped pop & $1.70^{\mathrm{c}}$ & $9.665^{\mathrm{a}}$ & $1.685^{\mathrm{a}}$ \\
corn & &
\end{tabular}

Note: Values in each row having the same letters are not significantly different $(\mathrm{p}>0.05)$. Values in each column having the superscript values are not significantly different $(p>0.05)$.

\section{CONCLUSION}

The data indicate that commercial corn and wheat products vary greatly in term of protein, fats and crude fiber contents. The variability observed in carbohydrates, protein, fats, ash content, crude fiber and moisture content is both genetic and environmental which may influence the individual chemical composition. These results will be useful to know about the nutritional properties of commercial corn and wheat products and Food composition data is important in designing strategies for nutritional planning and provides data for epidemiological studies.

\section{REFERENCES}

AACC. (2000). Approved Methods of the American Association of Cereal Chemists. American Association of Cereal Chemists, Inc; St Paul, Minnesota USA. http://dx.doi.org/10.1002/star.19890411114

Afzal, M., Nazir, Z., Bashir, M.H.B.S. \& Khan,B.S (2009). Analysis of host plant resistance in some genotypes of maize against Chilopartellus (swinhoe) (pyralidae: lepidoptera). Pakistan. Journal of Botany, 41, 421-428.

Akram, S. 2011. Assessment of nutritive quality and aflatoxin content of commercially available corn product,MSc. (Hons.) Thesis.Dept. Chem. Biochem. Univ. Agri. Faisalabad, Pakistan.

Ali, M., Ali,W., Ahmed,S. \& I. Ullah.(2008). Mineral Composition, Quality and Physico chemical Parameters of the Local Tallow of Pakistan. Pakistan Journal of Nutrition, 7, 717-720. http://dx.doi.org/10.3923/pjn.2008.717.720

Baloch, U.K., Irshad, M. (1986). Post-harvest research on food grains in Pakistan (A Review). Pakistan Agriculture Research Council, 2, 45-46.

Carvalho, V.P., Ruas, C.F., Ferreira, J.M., Moreira, R.M.P. \& Ruas, P.M.(2004).Genetic diversity among maize (Zea mays L.) landraces assessed by RAPD markers.Genetics and Molecular Biology. 27,228-236. http://dx.doi.org/10.1590/s1415-47572004000200017

Kadam, M.L., Salve, M.L., Mehrajfatema,Z.M. \& More.S.G.(2012) Development and evaluation of composite flour for missi roti /chapatti. Journal of Food Processing Technology. 3, 122-125. http://dx.doi.org/10.4172/21577110.1000134

Khan, A., Jan, M.T., Marwat, K.B. \& Arif, M. (2009). Organic and inorganic nitrogen treatments effects on plant and yield attributes of maize in a different tillage systems. Pakistan Journal of Botany. 41, 99-108.

Kulp, K., and Ponte, J.G. (2000). Handbook of cereal science \&technology. New York, NY: Marcel Dekker. pp. 431-438.

Niaz, I., Dawar, S.(2009).Detection of seed borne mycoflora in maize (Zea mays L.). Pakistan Journal of Botany. 41,443-451.

Nielsen, M.M., Hansen, A. (2008). Rapid High-Performance Liquid Chromatography Determination of Tocopherols and Tocotrienols in Cereals. Cereal Chemistry. 85, 248-251. http://dx.doi.org/10.1094/cchem-85-2-0248

Padovani, R.M., Lima, D.M., Fernando, A.B.C., \& Rodriguez-Amaya,D.B (2007). Comparison of proximate, mineral and vitamin composition of common Brazilian and US foods. Journal of Food Composition and Analysis. 20, 733 738. http://dx.doi.org/10.1016/j.jfca.2007.03.006 .

Panfili, G., Fratianni, A., \& M. Irano, M. (2003). Normal phase highperformance liquid chromatography method for the determination of tocopherols and tocotrienols in cereals. Journal of Agricultural and Food Chemistry. 51,3940-3944. http://dx.doi.org/10.1021/jf030009v .

PARC(2007).Status paper on maize, sorghum and millet.www.parc.gov.pk/1SubDivisions/NARCCSI/ $\quad$ CSI/StatusPaper.doc <http://www.parc.gov.pk/1Sub Divisions/NARCCSI/CSI/StatusPaper.doc>.

Parveen, S. (2007). Baking quality of wheat flour cookies supplemented with fiber from different sources. MSc. (Hons.) Thesis. Dept. Food Sci. Tech. Univ. Agri. Faisalabad, Pakistan.

Piironen, V., Syvaoja, E.L., Varo, P., Salminen, K., \& Koivistoinen, P. (1986) Tocopherol and tocotrienols in cereals from Finland. Cereal chemistry. 63, 78-81. http://dx.doi.org/10.1021/jf00070a038. 
Rehman, Z., (2011). Effect of supplementation of hydrocolloids and potato flour on the functional characteristics and shelf life of bread. MSc. (Hons.) Thesis. Dept. Food Sci. Tech. Univ. Agri. Faisalabad, Pakistan.

Steel, R.G.D., Torrie, J.H., and Dicky, D.A., (1997). Principles and Procedures of Statistics. A Biometrical Approach. (3rd Edition). McGraw Hill Book Co. Inc., New York.

Swiglo, A.G. and Sikorska, E. (2004). Simple reversed-phase liquid chromatography method for determination of tocopherols in edible plant oils. Journal of Chromatogry Analysis. 1048,195-198 http://dx.doi.org/10.1016/j.chroma.2004.07.051.

Zand, N., Chowdhry,B.Z., Zotor,F.B., Wray,D.S., Amuna, P., and Pullen, F.S.(2011). Essential and trace elements content of commercial infant foods in the UK. Food Chemistry. 128,123-128. http://dx.doi.org/10.1016/j.foodchem.2011.03.005 